Check for updates

Cite this: Chem. Commun., 2019, 55,2328

Received 11th January 2019

Accepted 30th January 2019

DOI: $10.1039 / c 9 c c 00274 j$

rsc.li/chemcomm

\section{Bisulfite-free and base-resolution analysis of 5-methylcytidine and 5-hydroxymethylcytidine in RNA with peroxotungstate $\uparrow$}

\author{
Fang Yuan, $\ddagger^{\mathrm{ab}}$ Ying $B \mathrm{~B}, \ddagger^{\mathrm{a}}$ Paulina Siejka-Zielinska, ${ }^{\mathrm{a}}$ Ying-Lin Zhou, (D) ${ }^{\mathrm{b}}$ \\ Xin-Xiang Zhang* ${ }^{*}$ and Chun-Xiao Song (DD*a
}

5-Methylcytosine $(5 \mathrm{mC})$ and 5-hydroxymethylcytosine $(5 \mathrm{hmC})$, two of the best-studied DNA modifications, play crucial roles in normal development and disease in mammals. Although 5-methylcytidine $\left(\mathrm{m}^{5} \mathrm{C}\right)$ and 5-hydroxymethylcytidine $\left(\mathrm{hm}^{5} \mathrm{C}\right)$ have also been identified in RNA, their distribution and biological function in RNA remain largely unexplored, due to the lack of suitable sequencing methods. Here, we report a base-resolution sequencing method for $\mathrm{hm}^{5} \mathrm{C}$ in RNA. We applied the selective oxidation of $\mathrm{hm}^{5} \mathrm{C}$ to trihydroxylatedthymine $\left({ }^{\text {th }} \mathrm{T}\right)$ mediated by peroxotungstate. ${ }^{\text {th }} \mathrm{T}$ was subsequently converted to T during cDNA synthesis using a thermostable group II intron reverse transcriptase (TGIRT). Base-resolution analysis of the $\mathrm{hm}^{5} \mathrm{C}$ sites in RNA was performed using Sanger sequencing. Furthermore, in combination with the TET enzyme oxidation of $\mathrm{m}^{5} \mathrm{C}$ to $\mathrm{hm}^{5} \mathrm{C}$ in RNA, we expand the use of peroxotungstate oxidation to detect $\mathrm{m}^{5} \mathrm{C}$ in RNA at base-resolution. By using this method, we confirmed three known $\mathrm{m}^{5} \mathrm{C}$ sites in human tRNA, demonstrating the applicability of our method in analyzing real RNA samples.

Epitranscriptome, which refers to the multitude of RNA chemical modifications, has vital roles in post-transcriptional gene regulation. ${ }^{1-3}$ 5-Methylcytidine $\left(\mathrm{m}^{5} \mathrm{C}\right)$ and 5-hydroxymethylcytidine $\left(\mathrm{hm}^{5} \mathrm{C}\right)$ are two of the major RNA modifications in eukaryotic cells, however, our understanding of them is still in its infancy. $\mathrm{M}^{5} \mathrm{C}$ is abundant in noncoding $\mathrm{RNA}$, and has the ability to stabilize tRNA secondary structure, ${ }^{4-6}$ but the knowledge about its distribution and function in mRNA are still very limited due to the inconsistent results obtained from the current sequencing methods. ${ }^{7-9} \mathrm{Hm}^{5} \mathrm{C}$ has been shown to be enriched in Drosophila melanogaster mRNA, increase mRNA translation and play a central

\footnotetext{
${ }^{a}$ Ludwig Institute for Cancer Research and Target Discovery Institute, Nuffield Department of Medicine, University of Oxford, OX3 7FZ, UK. E-mail: chunxiao.song@ludwig.ox.ac.uk

${ }^{b}$ Beijing National Laboratory for Molecular Sciences (BNLMS), MOE Key Laboratory of Bioorganic Chemistry and Molecular Engineering, College of Chemistry,

Peking University, Beijing 100871, China.E-mail: zxx@pku.edu.cn

$\dagger$ Electronic supplementary information (ESI) available. See DOI: 10.1039/ c9cc00274j

\$ These authors contributed equally.
}

role in Drosophila brain development. ${ }^{10} \mathrm{Hm}^{5} \mathrm{C}$ also exists in mammalian RNA, albeit at low levels, ${ }^{11}$ and the TET proteins that oxidize 5-methylcytosine $(5 \mathrm{mC})$ to 5 -hydroxymethylcytosine (5hmC) in DNA can also do so in RNA. ${ }^{10,12}$ However, the distribution and regulation roles of $\mathrm{hm}^{5} \mathrm{C}$ in the mammalian transcriptome remain unknown due to the lack of sensitive and robust sequencing methods.

The most common way to sequence $\mathrm{m}^{5} \mathrm{C}$ in RNA is to adopt bisulfite sequencing, which is widely used to sequence $5 \mathrm{mC}$ in DNA. Bisulfite treatment deaminates unmethylated cytosine to uracil in single-strand RNA, while leaving $\mathrm{m}^{5} \mathrm{C}$ unconverted. Therefore, bisulfite sequencing provides base-resolution information of $\mathrm{m}^{5} \mathrm{C}$. Using bisulfite sequencing, widespread $\mathrm{m}^{5} \mathrm{C}$ sites were identified in both coding and non-coding RNAs. ${ }^{7,8}$ However, bisulfite treatment employs sequential thermal acidic and alkaline conditions that severely damage the RNA. Further analysis also revealed potential false positives from RNA bisulfite sequencing due to incomplete conversion of unmethylated cytosine in the double-stranded RNA regions and other modifications resistant to bisulfite treatment. ${ }^{13-15}$ Other methods to sequence $\mathrm{m}^{5} \mathrm{C}$ in RNA are immunoprecipitation-based that use $\mathrm{m}^{5} \mathrm{C}$-specific antibodies or methyltransferases to pull down $\mathrm{m}^{5}$ C-containing RNA. ${ }^{16-18}$ These methods, however, do not have base-resolution and lose the quantitative levels of $\mathrm{m}^{5} \mathrm{C}$. Mapping $\mathrm{hm}^{5} \mathrm{C}$ in RNA is even more challenging. To date, there is no base-resolution sequencing method for $\mathrm{hm}^{5} \mathrm{C}$. The only reported method is the antibody-based immunoprecipitation approach. ${ }^{10}$ This method has been applied to the Drosophila transcriptome, but has yet to be successful in the mammalian transcriptome. Clearly, new RNA-friendly and high-resolution sequencing methods are highly desirable to further study the elusive distribution, localization and biological roles of these two modifications in RNA. Here, we report bisulfite-free and base-resolution sequencing methods for $\mathrm{hm}^{5} \mathrm{C}$ and $\mathrm{m}^{5} \mathrm{C}$ based on peroxotungstate oxidation.

Peroxotungstate oxidation was first developed by the Okamoto group $^{19,20}$ for selective oxidation of $5 \mathrm{hmC}$ in DNA to trihydroxylatedthymine $\left({ }^{\mathrm{th}} \mathrm{T}\right) .{ }^{\mathrm{th}_{\mathrm{T}}} \mathrm{T}$ is a thymine derivative, and will induce C-to- $\mathrm{T}$ 
a
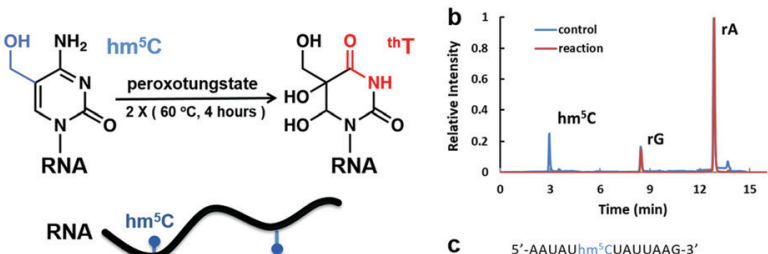

C 5'-AAUAUhm C CUAUUAGG $^{\prime}$

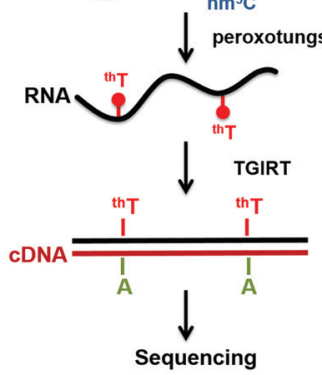

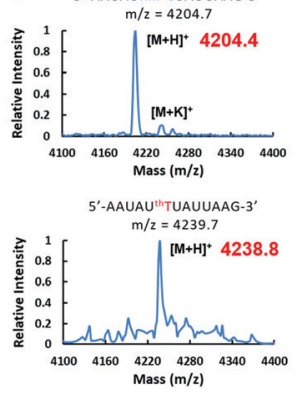

Fig. 1 Peroxotungstate reaction on $\mathrm{hm}^{5} \mathrm{C}$-containing RNA. (a) Illustration of the peroxotungstate reaction and workflow of WO-Seq. $\mathrm{Hm}^{5} \mathrm{C}$ containing RNA is specifically oxidized by peroxotungstate, and then reverse transcribed by thermostable group II intron reverse transcriptase (TGIRT). The oxidation product of $\mathrm{hm}^{5} \mathrm{C}\left({ }^{\text {th }} \mathrm{T}\right)$ is converted to $\mathrm{T}$ during cDNA synthesis, thus can be used for base-resolution sequencing of $\mathrm{hm}^{5} \mathrm{C}$ in RNA. (b) HPLC-MS/MS results of the hydrolysed product of synthesized $\mathrm{hm}^{5} \mathrm{C}$-containing RNA1 before and after the peroxotungstate reaction. Peaks of adenosine $(\mathrm{rA})$, guanosine $(\mathrm{rG})$ and $\mathrm{hm}^{5} \mathrm{C}$ are labelled in the figure. (c) MALDI-MS characterization of an $\mathrm{hm}^{5} \mathrm{C}$-containing RNA fragment of RNA1 treated with peroxotungstate. Calculated $\mathrm{m} / \mathrm{z}$ is shown in black, observed $\mathrm{m} / \mathrm{z}$ is shown in red.

transition in DNA after PCR. However, the peroxotungstate oxidation reaction requires single-strand DNA. The reaction is strongly inhibited in double-strand DNA with a conversion rate of less than $10 \%$, which severely limits its application. ${ }^{20}$ Although this reaction is not suitable for DNA samples, we hypothesized that it could be ideal to detect $\mathrm{hm}^{5} \mathrm{C}$ in RNA, which is mostly single-stand (Fig. 1a). We termed this approach peroxotungstate oxidation sequencing (WO-Seq).

We started with optimizing the oxidation conditions of the peroxotungstate against in vitro-transcribed $\mathrm{hm}^{5} \mathrm{C}$-containing RNA1. MALDI-TOF MS and HPLC-MS/MS were used to monitor the reaction rate. After two rounds of 4 hours incubation at $60{ }^{\circ} \mathrm{C}$, the $\mathrm{hm}^{5} \mathrm{C}$ peak in HPLC-MS/MS was undetectable (Fig. 1b), and the MALDI peak of RNA fragments containing one $\mathrm{hm}^{5} \mathrm{C}$ changed from $\mathrm{m} / \mathrm{z}=4204.4$ to $\mathrm{m} / \mathrm{z}=4238.8$. This is consistent with the calculated $\mathrm{m} / \mathrm{z}$ change from $\mathrm{hm}^{5} \mathrm{C}$-containing RNA to ${ }^{\text {th }}$ T-containing RNA (Fig. 1c). Sensitivity of the peroxotungstate treatment for $\mathrm{hm}^{5} \mathrm{C}$ was also tested (Fig. S1, ESI $\dagger$ ). Samples of different combination of $\mathrm{hm}^{5} \mathrm{C}$ modified RNA and unmodified RNA were treated by peroxotungstate, and then analysed by HPLC-MS/MS. The conversion rates of $\mathrm{hm}^{5} \mathrm{C}$ were similar in all samples, indicating that the peroxotungstate treatment is suitable for real biological samples which has low $\mathrm{hm}^{5} \mathrm{C}$ content.

Next, we investigated the potential of the $\mathrm{hm}^{5} \mathrm{C}$-to-T transition during cDNA synthesis using the peroxotungstate-oxidized RNA template. We designed and synthesized a 73mer RNA that contained three $\mathrm{hm}^{5} \mathrm{C}$ sites (RNA2). To enable us to monitor the efficiency of the $\mathrm{hm}^{5} \mathrm{C}$-to-T conversion, one $\mathrm{hm}^{5} \mathrm{C}$ was positioned
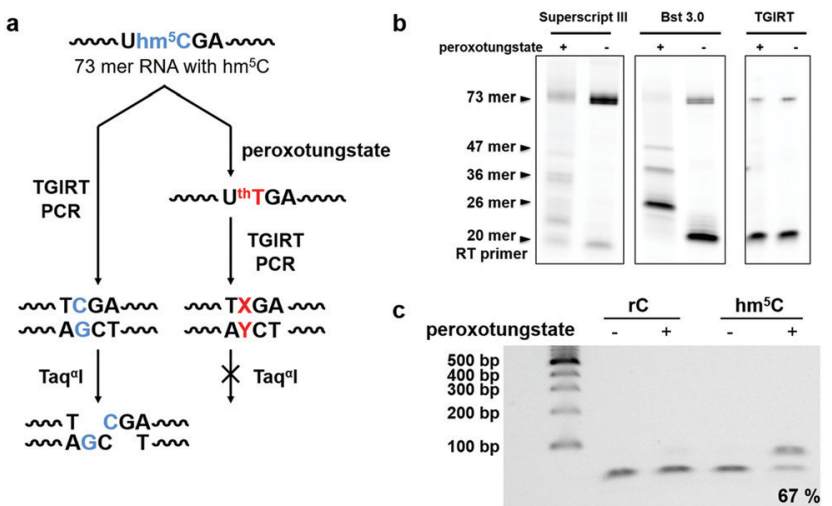

Fig. 2 Restriction enzyme digestion assay showed effective base change during CDNA synthesis using the peroxotungstate-oxidized RNA template. (a) Illustration of the restriction enzyme digestion assay for the investigation of the base change mediated by peroxotungstate. $X$ represent $T$ or $A$ or $G$, while $Y$ is the complementary base of it. (b) Reverse transcription products of $\mathrm{hm}^{5} \mathrm{C}$-containing RNA2 before and after peroxotungstate treatment using different reverse transcriptases. $\mathrm{Hm}^{5} \mathrm{C}$-containing RNA2 has three $\mathrm{hm}^{5} \mathrm{C}$ sites at position 26, 36 and 47 . The full length is 73 mer. (c) RT-PCR product of the 73-mer model RNA2 containing a Taq ${ }^{\alpha}$ I cut site. Samples without peroxotungstate treatment and control normal cytidine $(\mathrm{rC})$ containing RNA2 treated with peroxotungstate were cleaved completely. About $67 \%$ of the reacted $\mathrm{hm}^{5} \mathrm{C}$-RNA amplified product stayed intact, indicating the loss of the restriction enzyme cut site and the successful base change.

so that, upon successful $\mathrm{hm}^{5} \mathrm{C}$-to-T conversion, a Taq ${ }^{\alpha}$ I restriction enzyme recognition site in the resulting RT-PCR product was destroyed (Fig. 2a). Since ${ }^{\text {th }} \mathrm{T}$ is not a natural occurring base, we first sought to investigate its behavior during cDNA synthesis. Several commercially available reverse transcriptases were tested on this RNA template. Interestingly, only the thermostable group II intron reverse transcriptase (TGIRT) ${ }^{21,22}$ could read though all reacted $\mathrm{hm}^{5} \mathrm{C}$ sites, while Superscript III and Bst 3.0 DNA polymerase induced truncations at the reacted $\mathrm{hm}^{5} \mathrm{C}$ sites (Fig. 2b). The reaction conditions of TGIRT were further optimized to get the best reverse transcription efficiency, and after subsequent PCR, the DNA products were digested with Taq ${ }^{\alpha}$. As shown in Fig. 2c, $67 \%$ of the PCR products from the oxidized $\mathrm{hm}^{5} \mathrm{C}$-containing RNA2 sample stayed intact after the Taq ${ }^{\alpha} \mathrm{I}$ treatment, indicating loss of restriction enzyme cut site and the successful base change induced by the peroxotungstateoxidized RNA during cDNA synthesis.

We then performed Sanger sequencing of the PCR product from the oxidized RNA samples (Fig. 3). At each $\mathrm{hm}^{5} \mathrm{C}$ site, a new peak of thymine signal appears, confirming the base change is indeed C-to-T. In order to accurately quantify the C-to-T conversion rate, the PCR product was cloned and sequenced individually. A $62.1 \%$ conversion rate was observed from a total of 66 $\mathrm{hm}^{5} \mathrm{C}$ sites sequenced (Fig. S2, ESI $\dagger$ ), consistent with the restriction enzyme digestion result. As a control, PCR products of peroxotungstate-treated normal cytosine (rC)-containing RNA2 and $\mathrm{m}^{5} \mathrm{C}$-containing RNA2 were also cloned and sequenced (Fig. S3, ESI $\dagger$ ). Results showed that both $\mathrm{rC}$ and $\mathrm{m}^{5} \mathrm{C}$ sites did not change after the treatment, indicating an excellent selectivity of peroxotungstate oxidation on $\mathrm{hm}^{5} \mathrm{C}$. 

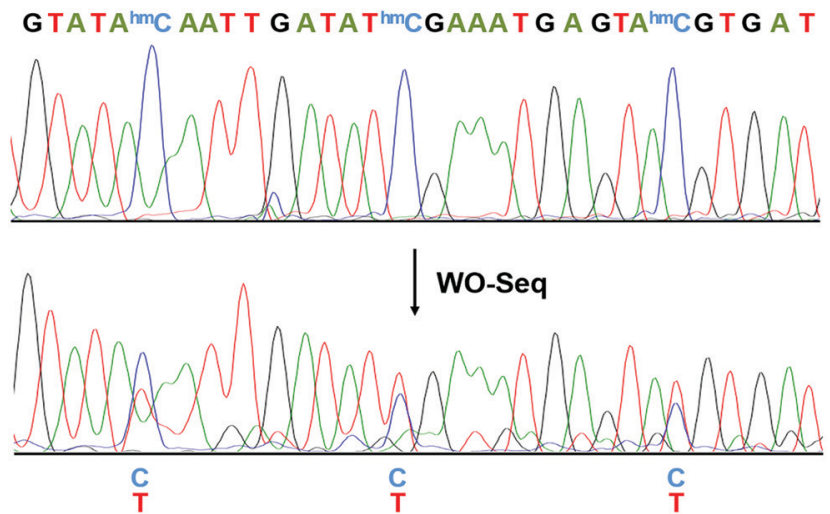

Fig. 3 Electropherograms of Sanger sequencing results before and after WO-Seq. The conversion of $\mathrm{C}$-to-T happened at each $\mathrm{hm}^{5} \mathrm{C}$ site.

Notably, peroxotungstate oxidation is a mild reaction, which showed less damage on RNA compared with bisulfite reaction (Fig. S4, ESI $\dagger$ ).

After demonstrating WO-Seq for $\mathrm{hm}^{5} \mathrm{C}$ sequencing, we next sought to expand its use for $\mathrm{m}^{5} \mathrm{C}$ sequencing in RNA. In DNA, $5 \mathrm{hmC}$ is generated by the oxidation of $5 \mathrm{mC}$ mediated by the TET enzyme. Recently, the mammalian TET enzyme was reported to have the ability of oxidizing $\mathrm{m}^{5} \mathrm{C}$ to $\mathrm{hm}^{5} \mathrm{C}$ in RNA. ${ }^{12}$ We tested Naeglaria Tet-like oxygenase (NgTET1 $)^{23}$ and showed it can also oxidize $\mathrm{m}^{5} \mathrm{C}$ to $\mathrm{hm}^{5} \mathrm{C}$ on $\mathrm{m}^{5} \mathrm{C}$-containing RNA1 by both MALDI-MS and HPLC-MS/MS (Fig. S5, ESI $\dagger$ ). Based on this, we further aimed to combine the peroxotungstate oxidation with NgTET1 oxidation to detect $\mathrm{m}^{5} \mathrm{C}$ in a procedure we termed TETAssisted WO-Seq (TAWO-Seq) (Fig. 4a). The results of both oxidation reactions were verified by HPLC-MS/MS (Fig. S6, ESI $\dagger$ ). Restriction enzyme digestion assays and Sanger sequencing were performed (Fig. 4b and c). Sanger sequencing results showed the C-to-T transition at each $\mathrm{m}^{5} \mathrm{C}$ site. The $\mathrm{m}^{5} \mathrm{C}$-to-T conversion rate was $50 \%$ estimated by restriction enzyme analysis, lower than that of $\mathrm{hm}^{5} \mathrm{C}$, due to incomplete $\mathrm{m}^{5} \mathrm{C}$ to $\mathrm{hm}^{5} \mathrm{C}$ oxidation by NgTET1 (Fig. S6, ESI $\dagger$ ). We also cloned and sequenced individual PCR product for the $\mathrm{m}^{5} \mathrm{C}$ sample. As shown in Fig. S7 (ESI $\dagger$ ), $33.3 \%$ of the total $\mathrm{m}^{5} \mathrm{C}$ sites were successfully detected. Commercially available mouse Tet1 (mTet1) was also tested for the TAWO-Seq, which gives similar results with NgTET1 (Fig. S8a, ESI $\dagger)$. We further demonstrated that $\beta$-glucosyltransferase $(\beta \mathrm{GT})$ can label $\mathrm{hm}^{5} \mathrm{C}$ with glucose and thereby protect it from peroxotungstate oxidation (Fig. S9, ESI $\dagger$ ). Combining $\beta \mathrm{GT}$ protection with TAWO-Seq could therefore enable it to detect $\mathrm{m}^{5} \mathrm{C}$ specifically.

To further demonstrate the utility of TAWO-Seq on real RNA sample, we applied it to the endogenous tRNA ${ }^{\mathrm{Asp}(\mathrm{GUC})}$ in $293 \mathrm{~T}$ cells. The tRNA ${ }^{\text {Asp(GUC) }}$ contains three known $\mathrm{m}^{5} \mathrm{C}$ sites at structural positions 38, 47 and 48 (Fig. S10a, ESI $\dagger$ ). ${ }^{24-26}$ Both NgTET1 and mTet1 were used to oxidize the tRNA and the products were then treated with peroxotungstate. The RT-PCR product of treated tRNA ${ }^{\mathrm{Asp}(\mathrm{GUC})}$ was cloned and sequenced. As shown in Fig. S10b and c (ESI $\dagger$ ), 35.2\% of the $\mathrm{m}^{5} \mathrm{C}$ sites were successfully detected with NgTET1 assisted WO-Seq, and 37.5\% of the $\mathrm{m}^{5} \mathrm{C}$ sites were detected using mTet1 assisted WO-Seq, a

C
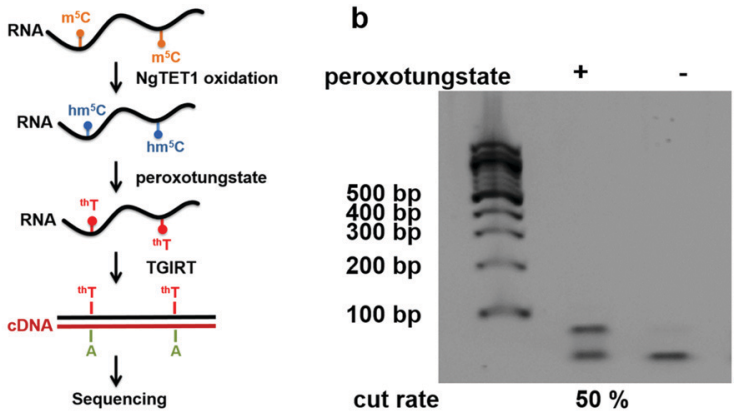

G TATA $m^{5}$ CAAT T G ATAT $m^{5}$ CGAAA T G A GTAm ${ }^{5}$ CGT G A T
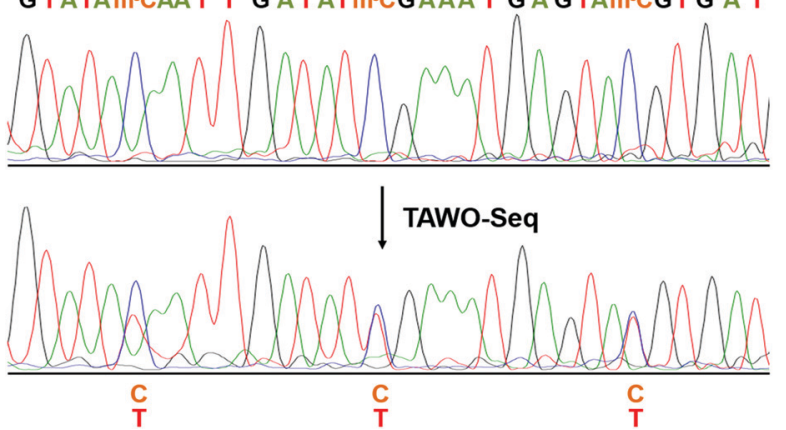

Fig. 4 The combination of NgTET1 oxidation and peroxotungstate reaction in detecting $\mathrm{m}^{5} \mathrm{C}$ in RNA in TAWO-Seq. (a) Illustration of TAWO-Seq strategy for the identification of $\mathrm{m}^{5} \mathrm{C}$ in RNA at single-nucleotide resolution. (b) Restriction enzyme digestion assay of $(+)$ and (-) NgTET1-assisted peroxotungstate-treated samples. About $50 \%$ of the $\mathrm{m}^{5} \mathrm{C}$ sites were detected. (c) Sanger-sequencing results before and after TAWO-Seq.

which demonstrated the applicability of TAWO-Seq to real RNA samples. Among the three $\mathrm{m}^{5} \mathrm{C}$ sites in $\mathrm{tRNA}^{\mathrm{Asp}(\mathrm{GUC})}$, we found that $\mathrm{m}^{5} \mathrm{C}$ at position 48 has the highest C-to-T conversion rate (68.4\% by NgTET1 assisted WO-Seq, $77.8 \%$ by mTet1 assisted WO-Seq). According to the tRNA ${ }^{\text {Asp(GUC) }}$ structure, this site is in a double-stranded CpG context, which is an ideal substrate of TET enzyme. ${ }^{23}$ It is likely that the different $\mathrm{m}^{5} \mathrm{C}$-to-T conversion rates of three $\mathrm{m}^{5} \mathrm{C}$ sites are caused by the sequence preference of the TET proteins.

In conclusion, we have described WO-Seq as an RNA friendly, chemical oxidation-based, base-resolution method to sequence $\mathrm{hm}^{5} \mathrm{C}$ in RNA. We demonstrate the specific $\mathrm{hm}^{5} \mathrm{C}$-to-T transition using peroxotungstate to oxidize the RNA followed by cDNA synthesis with the TGIRT enzyme, and Sanger sequencing results have proved the base-resolution sequencing ability of this method. We further demonstrate the ability of TAWOSeq to detect $\mathrm{m}^{5} \mathrm{C}$ by combining WO-Seq with the prior NgTET1 or mTet1 oxidation of $\mathrm{m}^{5} \mathrm{C}$ to $\mathrm{hm}^{5} \mathrm{C}$. The successful detection of $\mathrm{m}^{5} \mathrm{C}$ sites in human tRNA demonstrates our method is applicable for real RNA samples. Both WO-Seq and TAWO-Seq could potentially solve the false positive issue of bisulfite sequencing since they directly detect modified cytosine without affecting unmodified cytosine. Further improvement of both methods to increase the conversion rate and apply to mRNA samples using next-generation sequencing technology are underway in the lab. We believe this method could be highly useful for the identification of unexplored $\mathrm{m}^{5} \mathrm{C} / \mathrm{hm}^{5} \mathrm{C}$ distribution and function in the transcriptome. 
We would like to acknowledge P. Spingardi, G. Berridge and B. Kessler for helping with the HPLC-MS/MS; C. He for the mTet1; F. Howe for editing the manuscript. This work was supported by the Ludwig Institute for Cancer Research. Work in the C.-X. Song lab is also supported by Cancer Research UK (C63763/A26394 and C63763/A27122), NIHR Oxford Biomedical Research Centre, and Conrad N. Hilton Foundation. The views expressed are those of the authors and not necessarily those of the NHS, the NIHR or the Department of Health. F. Yuan and Y. Bi are supported by China Scholarship Council.

\section{Conflicts of interest}

There are no conflicts to declare.

\section{Notes and references}

1 Y. Saletore, K. Meyer, J. Korlach, I. D. Vilfan, S. Jaffrey and C. E. Mason, Genome Biol., 2012, 13, 175.

2 M. A. Machnicka, K. Milanowska, O. Osman Oglou, E. Purta, M. Kurkowska, A. Olchowik, W. Januszewski, S. Kalinowski, S. Dunin-Horkawicz, K. M. Rother, M. Helm, J. M. Bujnicki and H. Grosjean, Nucleic Acids Res., 2013, 41, D262-D267.

3 M. Frye, S. R. Jaffrey, T. Pan, G. Rechavi and T. Suzuki, Nat. Rev. Genet., 2016, 17, 365.

4 J. E. S. a. B. S. Cooperman, Biochemistry, 1992, 31, 10825-10834.

5 H. S.-G. Y. Chen, R. Guenther, K. Everett and P. F. Agris, Biochemistry, 1993, 32, 10249-10253.

6 Y. Motorin and M. Helm, Biochemistry, 2010, 49, 4934-4944.

7 M. Schaefer, T. Pollex, K. Hanna and F. Lyko, Nucleic Acids Res., 2009, 37, e12.

8 J. E. Squires, H. R. Patel, M. Nousch, T. Sibbritt, D. T. Humphreys, B. J. Parker, C. M. Suter and T. Preiss, Nucleic Acids Res., 2012, 40, 5023-5033.

9 X. Yang, Y. Yang, B.-F. Sun, Y.-S. Chen, J.-W. Xu, W.-Y. Lai, A. Li, X. Wang, D. P. Bhattarai, W. Xiao, H.-Y. Sun, Q. Zhu, H.-L. Ma, S. Adhikari, M. Sun, Y.-J. Hao, B. Zhang, C.-M. Huang, N. Huang, G.-B. Jiang, Y.-L. Zhao, H.-L. Wang, Y.-P. Sun and Y.-G. Yang, Cell Res., 2017, 27, 606 .
10 F. W. Benjamin Delatte, L. V. Ngoc, E. Collignon, E. Bonvin, R. Deplus, E. Calonne, B. Hassabi, P. Putmans, S. Awe, C. Wetzel, J. Kreher, R. Soin, C. Creppe, P. A. Limbach, C. Gueydan, V. Kruys, A. Brehm, S. Minakhina, M. Defrance, R. Steward and F. Fuks, Science, 2016, 351, 282-285.

11 H. Y. Zhang, J. Xiong, B. L. Qi, Y. Q. Feng and B. F. Yuan, Chem. Commun., 2016, 52, 737-740.

12 L. Fu, C. R. Guerrero, N. Zhong, N. J. Amato, Y. Liu, S. Liu, Q. Cai, D. Ji, S. G. Jin, L. J. Niedernhofer, G. P. Pfeifer, G. L. Xu and Y. Wang, J. Am. Chem. Soc., 2014, 136, 11582-11585.

13 S. Hussain, J. Aleksic, S. Blanco, S. Dietmann and M. Frye, Genome Biol., 2013, 14, 215.

14 W. V. Gilbert, T. A. Bell and C. Schaening, Science, 2016, 352, 1408-1412.

15 A. Shafik, U. Schumann, M. Evers, T. Sibbritt and T. Preiss, Biochim. Biophys. Acta, Gene Regul. Mech., 2016, 1859, 59-70.

16 S. Edelheit, S. Schwartz, M. R. Mumbach, O. Wurtzel and R. Sorek, PLoS Genet., 2013, 9, e1003602.

17 V. Khoddami and B. R. Cairns, Nat. Biotechnol., 2013, 31, 458-464.

18 S. Hussain, A. A. Sajini, S. Blanco, S. Dietmann, P. Lombard, Y. Sugimoto, M. Paramor, J. G. Gleeson, D. T. Odom, J. Ule and M. Frye, Cell Rep., 2013, 4, 255-261.

19 A. Okamoto, K. Sugizaki, A. Nakamura, H. Yanagisawa and S. Ikeda, Chem. Commun., 2011, 47, 11231-11233.

20 G. Hayashi, K. Koyama, H. Shiota, A. Kamio, T. Umeda, G. Nagae, H. Aburatani and A. Okamoto, J. Am. Chem. Soc., 2016, 138, 14178-14181.

21 S. Mohr, E. Ghanem, W. Smith, D. Sheeter, Y. Qin, O. King, D. Polioudakis, V. R. Iyer, S. Hunicke-Smith, S. Swamy, S. Kuersten and A. M. Lambowitz, RNA, 2013, 19, 958-970.

22 S. T. Carrell, Z. Tang, S. Mohr, A. M. Lambowitz and C. A. Thornton, Nucleic Acids Res., 2018, 46, e1-e1.

23 J. E. Pais, N. Dai, E. Tamanaha, R. Vaisvila, A. I. Fomenkov, J. Bitinaite, Z. Sun, S. Guan, I. R. Corrêa, C. J. Noren, X. Cheng, R. J. Roberts, Y. Zheng and L. Saleh, Proc. Natl. Acad. Sci. U. S. A., 2015, 112, 4316-4321.

24 M. G. Goll, F. Kirpekar, K. A. Maggert, J. A. Yoder, C.-L. Hsieh, X. Zhang, K. G. Golic, S. E. Jacobsen and T. H. Bestor, Science, 2006, 311, 395-398.

25 M. Schaefer, T. Pollex, K. Hanna and F. Lyko, Nucleic Acids Res., 2009, 37, e12-e12.

26 W. A. Cantara, P. F. Crain, J. Rozenski, J. A. McCloskey, K. A. Harris, X. Zhang, F. A. P. Vendeix, D. Fabris and P. F. Agris, Nucleic Acids Res., 2011, 39, D195-D201. 